\title{
The Case of Kabylia: Explaining Elective Affinities in Bourdieu's Mediterranean
}

Geoffrey Mead

Postcolonial Studies [Submitted version]

\begin{abstract}
A recurrent paradox accompanies Pierre Bourdieu's description of his relation to his earliest field site: the people of Kabylia are frequently evoked as 'at once exotic and familiar'. In the present article I ask what conditions must prevail for such a depiction to be possible. Taking up work conducted in recent years concerning the details of Bourdieu's fieldwork, its theoretical presuppositions, and its place within the declining French empire, I propose that Bourdieu's depiction is predicated on what Herzfeld calls 'practical Mediterraneanism': an ideology of the Mediterranean as a cultural region that permits Bourdieu to negotiate his colonial position, by transmuting a power relation into a relation of cultural similarity. Yet I aim to avoid imputing to Bourdieu a subjective failing in this regard, whether through cynical manipulation or simple error. Instead, pausing on the performative dimension of Bourdieu's texts, I examine what his representations of the Kabyle do throughout his oeuvre and how these are bound by particular intellectual, existential, and political problems that arise at different times.
\end{abstract}


A recurrent paradox accompanies Pierre Bourdieu's description of his relation to his earliest field site: the people of Kabylia are frequently evoked as 'at once exotic and familiar'. This peculiar coincidence of opposites is often explained by recourse to Bourdieu's own biography, with the explicit suggestion that it was his personal identification with the Kabyles, rooted in a rural temperament, that enabled this intellectual claim. This is best captured in a memory that Yacine relates:

the culture of the colonised exercised on him the effect of a magnifying mirror, to the point that he came to define himself as Kabylo-Béarnais: "Like you, the culture of the other (Kabyle culture), transformed me and allowed me to see myself otherwise". ${ }^{1}$

Albera appropriates Yacine's mirror metaphor and asserts that, in Bourdieu's work, the Mediterranean Sea 'above all remains the space for a mirror game between familiarity and alterity'. It follows from this that '[ $t$ ]he other is no longer the bearer of this radical alterity, by which one distances oneself from him to better reify him'. As Bensa proposes, the Kabyle is Bourdieu's 'alter ego'. Thus, ethnographic work 'on the other becomes, inseparably, work on the self'. ${ }^{2}$ To reify this specular metaphor, it amounts to recognising oneself in the reflection thrown back by another. In Bourdieu's terminology, we can register this as allodoxia: a 'false recognition founded on the misrecognised relation between two histories that brings one to recognise oneself in another history, that of another nation or another class'. ${ }^{3}$ This definition, however, for now serves only to defer an answer by begging the question of what characterises an 'other' history.

While questions pertaining to 'our' identity in relation to 'others' are so frequent as to be ritualistic incantations, the prospect of untangling their terms in Bourdieu's work offers specially important rewards, given several interlinked peculiarities that characterise it. The first peculiarity concerns Bourdieu's own biographical circumstances, in particular his peripheral, rural upbringing. Given that Bourdieu's second field site, in which he conducted research almost contemporaneous with his Algerian work, was his native town, his biography becomes immediately implicated. But does this mean that we can, as Bourdieu does as much as his commentators, explain his attitude to the other on the basis of a shared rural cultural background? A second peculiarity concerns Bourdieu's implication in studies of 'Mediterranean' cultures and his casting of the Kabyle culture-along with his own Béarnais culture - as one of several such groups belonging to this region. This is a region whose existence has been mired in scholarly controversy, given certain accusations made of it, namely, that it assumes and redoubles local stereotypes. Negating and inverting Bourdieu's 
expansive description of the Kabyle, as both exotic and familiar, Herzfeld asserts that the cultures that populate the region are 'neither exotic nor wholly familiar'. Like 'matter out of place', they refuse to be assimilated into conventional categories. The Mediterranean region as a whole, then, "is "not us", even though we claim it as "our own". 4 Compounding this unhomely character of the Mediterranean is the final peculiarity, namely, the fact of Bourdieu's ambivalent position within the fading French colonial project in Algeria. At once a member of the military and an opponent of Algérie française, dependent on the works of orientalists but critical of their positions, Bourdieu is characteristically idiosyncratic. Not merely does the Mediterranean region ostensibly contain shared cultures, then, but those belonging to these cultures maintain antagonistic relations, no more intense than the time that Bourdieu was undertaking his fieldwork. To see oneself in the other acquires particular intensity here.

So, it is not possible to treat Bourdieu's depiction of the Kabyle outside of his biographical circumstances. Furthermore, given Bourdieu's recourse to the Mediterranean region as a way of justifying the parallels between Kabylia and his own Béarn village, it is useful to consider the impact of this region on his depiction. Finally, the French-Algerian colonial relation compels us to treat the issue of power relations between French groups like the Béarnais and colonised Algerian groups like the Kabyle. A number of authors have explored the parallel between the two in Bourdieu's work generally, and have mostly noted the surprising absence of a systematic exploration of it by Bourdieu himself. Most explicitly, Reed-Danahay writes that, '[i]n reading these two almost identical descriptions of village peasant life, I cannot help but wonder why Bourdieu did not make these resemblances between the two locations more a part of his theoretical analysis'. She adds that those comparisons that he 'did make were in the form of footnotes, or asides'. 5 The task I set myself here begins with making sense of what Bourdieu is doing in these footnotes or asides when he makes reference to the cultural resemblances. Then we can better understand how Reed-Danahay's claim stands beside Bourdieu's own declaration that, 'I have always combined analysis of Kabylia with analysis of Béarn'. ${ }^{6}$

I argue that we can interpret Bourdieu's statements regarding the perceived close connection between Kabylia and Béarn as manifesting what Herzfeld calls 'practical Mediterraneanism'. This is a situated and pragmatic invoking of cultural stereotypes attributed to the Mediterranean cultural area intended to summon a pan-Mediterranean cultural unity. ${ }^{7}$ 
Herzfeld's focus is turned to the performative function of the practical reference to stereotypes. Just as a street merchant invokes the Mediterranean to sell amulets, for example, Bourdieu, I argue, invokes it for certain practical purposes. Therefore, as I assert throughout, I am interested less in following those who comment on Bourdieu's 'representations' of the Kabyle, than in what he does with these representations - both within his work and outside it. It is particularly interesting that Bourdieu invokes the Mediterranean with its implications of cultural coherence in the context of the Algeria's anti-colonial struggle and postcolonial situation. Thus, I argue that one of the functions of Bourdieu's 'practical Mediterraneanism' is to enable him at once to recognise and to efface the power relations that haunt his intuitive comparisons between French peasants and the Kabyle. It transmutes differences of power into similarities of culture.

\section{Bourdieu and colonialism: from the constative to the performative}

The question at issue here, that of how the Kabyle can be depicted as both exotic and familiar, takes us first to the growing discussion about Bourdieu's early Algerian fieldwork and the representations of the Kabyle contained therein. This is a discussion that as recently as 2003 was still muted, such that Goodman was then able to observe the following: 'Given Bourdieu's contributions and commitments, it is somewhat surprising that his work has remained largely outside the purview of the literature attentive to the political and ethical responsibilities of ethnographic representation'. 8 This literature, accumulating especially among Anglo-American anthropologists in the wake of Said's Orientalism, appeared to neglect Bourdieu, placing him within a stream of blameless 'practice theory'. The critical attention that his early work would come to receive concerned particularly whether the facts of colonialism and anti-colonial war were sufficiently present in his depiction. This literature has, on the whole, arrived at the position that Bourdieu neglected these phenomena (at least in those works that became popular in the Anglophone world). In line with the schema orienting the nascent studies in the 1960s of Mediterranean communities, it is argued, Bourdieu represented Kabylia as comprised of traditional, hermetic village communities untouched by French colonial education, for example, the Algerian bureaucratic apparatus, or even by the presence of a war in their midst.

So, as Martín-Criado writes, whether or not the sociologist neglected it, '[t]he Kabylia that Bourdieu knew, far from being a traditional society, was, in large part, the result of colonial 
politics'. This conclusion is certainly drawn by those who are overwhelmingly critical of Bourdieu for ostensibly erasing any trace of such politics within his works. ${ }^{9}$ But it also applies to those who seek to rehabilitate Bourdieu's early work by claiming that he was actually offering a kind of sociology of colonialism as well as an implicit critique. ${ }^{10}$ In fact, these positions are not mutually exclusive, and the criticism to which Bourdieu's work has been subjected has not resulted in a wholesale rejection of the early work in question. Rather, it has brought about a notably bifurcated evaluation of his work, embodied in what can be called the 'two Algerias' conception. ${ }^{11}$

According to this view, Bourdieu depicted Algeria and its people in two, divergent manners: first, as a country devastated by approximately 130 years of French colonialism and the brutal imposition of a capitalist economy, not to mention the anti-colonial war. Second, Bourdieu depicted Algeria, or at least rural Algeria, as a timeless home for people like the Kabyle Berbers, illiterate and tied to the land, ignorant of monetary exchange, and fastened to rituals operating from time immemorial. This latter depiction of Algeria manifests itself in such 'anthropological' works as Outline of a theory of practice, while the former depiction, ostensibly lesser-known, appears in more 'sociological' works like Travail et travailleurs en Algérie. The two 'appear side by side, albeit fleetingly' in only one text, Bourdieu's first monograph, Sociologie de l'Algérie. ${ }^{12}$ In any case, the ambivalence in Bourdieu's casting of the Kabyle means that they often appear in different roles according to the text in which they find themselves. Perhaps this internal bifurcation goes some of the way to explaining how the broad and varied collection of critics that has emerged over the years offers us no resolution to the question driving this paper: what makes possible Bourdieu's depiction of the Kabyle as both exotic and familiar? These commentators line up on a continuum ranging from early critics who saw Bourdieu resorting to exoticist and essentialist tropes in his depiction, to more recent critics, who observe a vacillation between familiarity and exoticism.

Even before the interpretive posture ushered in by Said's Orientalism, criticism of Bourdieu's characterisation of Kabyle society was apparent. Lacoste-Dujardin, for instance, reproached Bourdieu for describing in the Esquisse an ahistorical Kabyle society 'that goes back perhaps even to precolonial times'. Similarly, Said himself points out that Algeria as a political space, as well as the very fact of colonialism, are absent from Outline in particular. It is, for him, 'the exclusion of Algeria from Bourdieu's theorizing and ethnographical reflection in Outline that is noteworthy'. ${ }^{13}$ Likewise, Herzfeld argues that in such a text as Outline, there prevails 
an interest in hermetically sealed 'local' villages concerned above all with honour and shame, effacing any treatment of local-state relations or the political conditions that make local, faceto-face relations possible. Herzfeld's interest in this point ascends to the more abstract issue of exoticism, for he claims that by bifurcating the local from the national in such an artificial manner, Bourdieu 'hermetically separates the values of the local community from those of the encompassing bureaucratic and religious institutions'. This separation itself stands in for yet another, a 'false distinction between societies with codified laws and societies with a customary morality that can only be invoked retrospectively...in other words, between "us" and "them". ${ }^{14}$ Reed-Danahay, following Herzfeld's logic, mounts the claim that Bourdieu alternately 'Orientalises' Algeria as he 'Occidentalises' France, playing 'essentialised' versions of each off one another, highlighting for his Western readers at once the exotic character of the Algerians and the familiar character of the French. At issue most in ReedDanahay's discussion is her recurrent invoking of Bourdieu's ostensible 'essentialising', whether it pertains to his categories of the Orient and the Occident, or to his 'use of an essentialized dualism of "modern" and "traditional" societies' ${ }^{15}$ Clearly, the 'two Algerias' view refutes the idea that on the other side of the Mediterranean lies a 'traditional' society, counterposed to a 'modern' France. Similarly, Bourdieu's ethnography in rural France suggests that 'modernity' is, in his eyes, at issue within the borders of that nation-state.

Lane begins the move away from seeing Bourdieu as merely unfairly exoticising the Kabyle. He notes that whatever the meaning conveyed by Bourdieu's portrayal, it is nevertheless the intention of the latter to attempt to subvert such dualism: "Such a classically modernist and ethnocentric opposition between "primitive" authenticity and "modern" alienation is surely belied by Bourdieu's readiness to draw direct analogies between structures of domination in Kabylia and those at work in the West'. It is pivotal for Bourdieu's broader anthropological theses that he draw these analogies, present as much in his transmutation of the concept of honor into that of symbolic capital, as it is in the elaboration of the concept of habitus contemporaneously on both sides of the Mediterranean. Much hinges on these analogies, yet as Lane points out Bourdieu appears to rest on the very opposition that he seeks to dismantle: to argue that, in fact, the West is more exotic than it is presumed to be, as demonstrated by the analogies that can be drawn between it and a place like Kabylia, is to imply that the Kabyle are in fact exotic. Therefore, Lane argues, 'Bourdieu tends to hypostatise rather than deconstruct the poles of the opposition he seeks to critique'. ${ }^{16}$ Reed-Danahay similarly argues in more recent works that the exotic/familiar polar opposition, as it manifests in Bourdieu's 
work, is similarly inextricably bound: no longer does she claim that, for Bourdieu, the Kabyle are pre-modern and the French modern, for familiarity and exoticism are both found among each, insofar as he used 'both rural cases as contrasts to "modern" French society, up until his very last writings'. Reed-Danahay by this point notes that the colonial history in which Bourdieu's writing was implicated perhaps leads him to overstate the similarity between nonArab Algerians, in particular, and the French. Thus, Bourdieu unwittingly took part in 'a wider ideology with a long history, in which the Berbers in North Africa were believed to share similarities with the provincial French, especially those in the south or in mountainous regions'. ${ }^{17}$

Such interventions as this point us in a more productive direction than the earliest discussions of Bourdieu's representations of the Kabyle that remain, predictably, on the level of the representation. That is, following Said's Orientalism, a focus on the representations themselves has remained, with their ramifications bracketed. In this way, the impetus of Said's initial argument, that these texts insert themselves in 'worldly' contexts, with associated material effects, is lost. ${ }^{18}$ This representational approach remains trapped in a kind of 'picture theory' of language, concerned with texts as external means of simply capturing a pre-existing situation, as if they persisted outside the reality they describe.

Concerns with representation appear beside concerns with the material entanglement of text and world in what is probably the most exhaustive account yet of the relation of Bourdieu's ethnography to its historical context. Observing along with those concerned about representations that 'the colonial location of Bourdieu's work is nearly impossible to discern from the Outline', Goodman and Silverstein bring together papers in Bourdieu in Algeria that aim to restore Bourdieu's categories to their conditions of production. ${ }^{19}$ These conditions comprise the concrete ethnographic circumstances of these concepts and their politicohistorical context. While questions of representation have been answered and exhausted, those pertaining to the precise material relations between the colonial project and Bourdieu's ethnographic practice and findings remain open. They claim that such a concept as habitus has travelled free of such a context, invisibly accompanied by those Kabyle who initially gave rise to it. This is a consequential claim, for if the scrutiny applied to Bourdieu's early studies demonstrates, as they assert, that his ethnography is predicated on a deformed Kabyle reality, then we must ask what such concepts do as they find themselves deployed in conditions outside those in which they were fabricated. 
Along with Martín-Criado, Goodman and Silverstein present the most persuasive case yet that Bourdieu's fieldwork remains saturated with mythical notions about Kabylia, beginning with his idealised conception of a people who no longer exist as such. Bourdieu himself cautions in various asides and footnotes that the Algeria he describes ought to be written about 'in the past tense' alone. That is, a peculiar mélange of colonialism and recent anticolonial war serves as a causal principle in the destruction of this culture that he nonetheless proceeds to describe. ${ }^{20}$ That this did not appear to alter his anthropological accounts of Kabyle culture leads Goodman and Silverstein to suggest that Bourdieu was led to mistake for timeless elements of 'traditional' practice what were in fact recent responses, 'the accommodations Algerians may have made to colonialism'. While they spend most of their piece enforcing this point, perhaps the more significant step their commentary makes is redirecting us from the representationalist approach that I mentioned above. In particular, as ethnographers of contemporary North Africa, they are concerned with how such idealised conceptions of Kabyle life have, with the ascension of Bourdieu's popularity, fed back into present practices of Berber activism, leaving the latter movement with a calcified conception of the history of the culture for which it advocates. Chachaou, by contrast, sees Bourdieu's contribution to the movement as largely negligible. ${ }^{21}$ In any case, and whatever the verdict on this particular issue, what is most important is the particular attitude toward the ethnography: not simply a synthesis of recorded observations, a passive - or mistaken - reflection of the world, with which the representationalist priority satisfies itself, but an active figure in the production of a world.

This shift, from conceiving representations as constative, seeking to capture and describe the world, to conceiving them as performative, inescapably affecting the world they purport to represent, takes us back to a concern with the relation between texts and the world in which they are enmeshed. Thus I ask, after Goodman and Silverstein, how does Bourdieu 'do things with representations'? More precisely, we can follow Skinner, who expresses this 'in terms of Austin's claim that we need to be able to understand what the speaker or writer may have been doing in saying what was said'. ${ }^{22}$ To properly mobilise this ethos, we need to focus on Bourdieu himself, for a time, as the exclusive focus on the purported 'other' here has impaired a proper response to our basic question. By turning to the ways in which the Kabyle are intertwined and replaced in a system of representations, within which Bourdieu's 'self- 
conception' (his representation of Béarn) is present, we are able to better determine what work they do within his work.

\section{The Kabyle mirror}

If we take seriously the metaphor of Kabylia as a peculiar mirror in whose reflection Bourdieu sees himself otherwise, then it is insufficient to consider his depiction of the Kabyle in a vacuum, that is, outside of his own self-perception. This leads us to consider their place within Bourdieu's work as a whole, to consider Bourdieu's depiction of them within the system of representations in which it occurs. We begin with the preponderance of links Bourdieu himself posits between the Kabyle and his own Béarnais people. It is thus crucial to consider Bourdieu's conception of himself within this system. The fact that in anecdotal reflection Bourdieu hardly invokes either Béarn or Kabylia without mentioning the other suggests a profound entanglement. Initiating such a line of thought, Certeau asks, 'is it possible to say which-Béarn or Kabylia — is the doublet of the other? ${ }^{23}$

This entanglement indicates, likewise, that it is just as difficult to consider Bourdieu's depiction of Béarn in isolation as it is to consider his depiction of Kabylia outside the former. I attempt to clarify this by drawing on Bourdieu's numerous remarks to the effect that there is a particular 'Mediterranean' quality that subtends their relation. Thus, the relation between them traverses the system of representations that comprises the 'Mediterranean' region. We can thereby begin to make sense of the uncanny, both exotic and familiar, position of the Kabyle, for this is intrinsic to the nature of such a category as the Mediterranean. As Herzfeld suggests, like 'matter out place', Mediterranean cultures resist assimilation into existing categories that render them either familiar or exotic, civilised or primitive. But this resistance to categorisation does not owe to an actually existing simultaneous cultural familiarity and distance. Rather it owes to an ethnocentric vision of the Mediterranean, which alternates between the roles of cradle of civilisation (typified by Ancient Greece) and fallen peasant land to the south. Thus, it is 'us', that from which we derive. However, it is removed from us by the unbridgeable distance of mythic time. ${ }^{24}$

The account of the Mediterranean to which Herzfeld contrasts his own has been termed by others an imperial or colonial one. Lorcin and Shepard, in a recent collection of historical work on the region, begin from the claim that 'the concept of this sea as a unified space is essentially a Western one, devised by the imperial powers that patrolled its seas and 
controlled its ports'. In opposition to this unified, 'monotheistic' vision, Chambers has called it a 'postcolonial sea', irreducible to the unitary conception. ${ }^{25}$ Rather than enter into a fruitless debate about its ontological status, I wish to pursue Herzfeld's performative line of inquiry and ask once again what such representations do.

Herzfeld introduces a notion of 'practical Mediterraneanism' to capture the quotidian instances in which this region and its associated stereotypes-like concern for honour and shame, for virility, and a practice of 'amoral familialism' - are invoked in the face of some kind of practical exigency. These range from the trivial need to excuse behavior all the way to political and commercial imperatives (selling the romantic Mediterranean to tourists, e.g.). Such everyday recourse to the region and its stereotypes has, for Herzfeld, the effect of bringing the region into existence, of reproducing its existence in the form of a 'practical accomplishment'. Thus, to invoke it is a speech act, fabricating the Mediterranean region as it ostensibly designates it: 'such culture-area categories have an existence by virtue of being articulated'. ${ }^{26}$ The benefit of such an approach, Herzfeld asserts, is that it enables us to escape irresolvable ontological questions - those of whether the region really exists outside representations made of it - and to determine what social effects its presumed existence has. Still, Herzfeld clearly rejects the presumption of a Mediterranean culture region as an analytical category. Essentially, anthropologists' presumed existence of the region leads them to resort to circular reasoning and therefore to redouble to power of the pre-existing stereotypes. Beginning with the premise that the cultures of this region are preoccupied with honour and shame, for example, the anthropologist seeks and finds proximate notions and presumes they are the translated form of this basic concept:

despite the meticulous ethnography in which they are presented, onore and honra and filotimo and nif and namus end up seeming to be always-already in place, awaiting only the ethnographer capable of recognizing - rather than constructing - their inherent mutual translatability, and their collective reducibility to the Englishlanguage term "honor". This is the besetting circularity of the Mediterraneanist model of honor and shame. ${ }^{27}$

The risk that anthropologists pose here appears to be on the level of unwittingly accepting stereotypes, giving legitimacy to the responses that people give daily as means of justifying some action or another. 
In Herzfeld's account, anthropologists lend authority to these regionalist claims. After granting this sanction, however, the intellectual disappears from view in this account. Yet, there are benefits to imposing this framework on such an intellectual as Bourdieu. That is, to treat him no different than those '[1]ocal people [who] invoke the idea of a shared Mediterranean identity for a variety of reasons.' ${ }^{28}$ It is especially pertinent because this approach is implicit in Bourdieu's own model. Indeed, Herzfeld here comes close to a Bourdieusian approach to the fuzzy, practical logic of categories. For Bourdieu, people deploy categories, like that of region, in their everyday dealings not merely with the goal of describing or representing the world, but with intervening in it in some way: 'practical classifications are always subordinated to practical functions and oriented towards the production of social effects'. The concept of region is exemplary in this regard, for what is at stake in '[s]truggles over ethnic or regional identity', Bourdieu writes, is the power to 'impose the legitimate definition of the divisions of the social world and, thereby, to make and unmake groups' ${ }^{29}$ This is apparent in a dialogue between Bourdieu and Mouloud Mammeri, as the former claims that, "[a]s soon as one says "the Kabyles", this exists a little.... If I change the way of naming things, I change things a little'. ${ }^{30}$ Bourdieu, like Herzfeld, notes that the sociologist risks granting authority, complete with the grandeur of an assumed objectivity, to the claims of those who have an interest in the existence of a region.

The danger of adopting regional categories is the risk of granting them objective existence by furnishing them with a scientific veneer. The reflexive approach aims to militate against this, as Bourdieu shows by studying Montesquieu's climate theory, which mobilised everyday geographic categories of the 'north' and 'south' to explain perceived cultural differences. Bourdieu claims that Montesquieu deployed contemporary scientific language to give credibility to what was in fact a mythological distinction, a 'phantasmal structure' ${ }^{31}$ In this way, Bourdieu treats Montesquieu as a kind of ethnographic subject. He later says that having 'read the text with Kabyle eyes, I immediately saw there an entirely Kabyle mythology, the North/South, the Hot/Cold... ${ }^{32}$ In a reflexive spirit, we can extend this treatment to Bourdieu himself. This is to interpret the categories intellectuals deploy as if they were practical schemes, as Pina-Cabral notes: '[i]t is time, then, for a rethinking of the notion of the Mediterranean-one that sees anthropologists as strategists, wheeler-dealers, and manipulators of power like Italian, Greek, and Spanish peasants' ${ }^{33}$ So, for what practical ends does Bourdieu deploy the notion of the Mediterranean? 
We must begin by placing Bourdieu historically amidst the post-war emergence of a sub-field of anthropology that took as its object the 'Mediterranean'. As others have noted, Bourdieu was one of the early contributors to the 'social anthropology of the Mediterranean', participating in a 1959 conference organised by Julian Pitt-Rivers, who collected the papers presented into Mediterranean countrymen. ${ }^{34}$ Bourdieu's approach can broadly be identified in Pitt-Rivers' introduction to this collection, which takes an explicit position against the analytical framework that assumes a nation-state with its national culture. There are, within the Mediterranean, Pitt-Rivers writes, 'both more similarities between different countries and more diversities within their national frontiers than the tenets of modern nationalism would have us believe'. Such a sentiment is axiomatic in Bourdieu's 'peasant' studies, at least, where similarities between groups within France and Algeria appear at the forefront. At issue in these similarities is not, for Pitt-Rivers, 'the formal comparison of cultural features but the implicit comparison between different instances of similar phenomena'.35 Bourdieu's tendency toward this is evident in this discussion of the relation between Béarnais customs and those of Kabylia:

In Béarn there were in each of the small valleys little autonomous republics, which had their own customs, etc. There were collections of customs, the equivalent of the Kabyle kanoun. There are many other analogies: the same masculine values, the same values of honour, very democratic assemblies. ${ }^{36}$

Here, Béarn and Kabylia appear flattened, manifesting as rural, pre-capitalist societies. Bourdieu suggests that they possess the 'same' values and customs, merely appearing under different guises. There is a presumed consistency between cultures. Therefore, in the face of an asymmetrical relation between those in the metropole and the colonised Algerians, one can find identity on the basis of a posited cultural sameness. Here we see one instance of Bourdieu's 'practical Mediterraneanism'.

Much has been written in particular about the relation between Kabylia and Bourdieu's own Béarnais region as it appears in his work. This relation is of interest not least because his early research was conducted contemporaneously: Bourdieu recalls that he and Sayad 'prepared Le Déracinement by night and, during the day, we went to do interviews in Béarn' ${ }^{37}$ This relation is also of interest because many have pointed to Bourdieu's biography as a way of explaining his frequent reference to this parallel. Being raised in Béarn, it is implied, he naturally feels a sense of affinity for the Kabyle. ${ }^{38}$ Indeed, Bourdieu himself 
expresses this biographical interpretation in several places. He sees in Sayad a reflection, recalling that upon bringing him to his village in Béarn, Sayad 'understood immediately, thus helping me to understand the roots of my interest for the Kabyle peasants'. He will add elsewhere that the similarities yielded ethnographic gains:

When I was in Kabylia, I mistrusted the old Kabyles, while admiring them very much, thinking to myself: "what is this man telling me about honour?"... And I said to myself: if it was an old Béarnais peasant who was telling me this, what would I think of it? $?^{39}$

Yet Bourdieu will also propose the contrary, referring to the Kabyle as foreign: '[h]aving worked in Kabylia, a foreign universe, I thought it would be interesting to do a kind of Tristes tropiques but in reverse...to observe the effects that objectivation of my native world would produce in me'. ${ }^{40}$ Given the coexistence of these opposites, we are again back where we began, with a relation to a group depicted as simultaneously familiar and exotic.

Others make sense of this contradiction by imputing to Bourdieu something of a cynical exploitation of his heritage to claim identity with the Kabyle, thus bolstering his empirical claims through extra-empirical means. Reed-Danahay writes that:

He also sought to legitimize his work in Algeria by using his own rural roots in France to claim a sort of 'insider' status among Kabyle peasants, and to distance himself from others associated with the colonial power of France. ${ }^{41}$

One can read his own statements, to the effect that his geographical origins endowed him 'with a number of properties that are not without parallel in the colonial situation', in these terms. ${ }^{42}$ Yet it would be a mistake to impute cynical and unverifiable subjective motives. Instead of seeing this as an attempt to legitimise his work, we can see it as a 'well-founded illusion', a genuine affinity founded not only in biography, but also in Bourdieu's theory, which posits, after all, homological identification. That is, if it is true that these properties have their colonial parallels, to be one of the 'internally colonised' does not efface one's position as a French metropolitan, 'objectively aligned with the colonizer in various ways, including legal and citizenship rights and social privileges'. ${ }^{43}$ One remains divided in this respect, both at the same time.

This is to say that rather than concentrating on subjective intentions, we ought to place Bourdieu within a context, in which it happens that these ambivalent statements are difficult 
to escape. As I suggested above, invoking Herzfeld's description of the cultures of the region as like 'matter out of place', given the objective categories that structure our perception and definition of it, the paradoxical relation Bourdieu maintains with the Kabyle inheres in the objective terms of the circumstance. A vacillation between coasts, so to speak, is a natural corollary to the terms. Furthermore, Bourdieu's deployment of the Mediterranean-as a positing of cultural continuity between cultures on opposite coasts - goes further than a kind of biographical equation of Béarn and Kabylia. As we will now see, Bourdieu seeks to implicate France - and beyond - in this region.

\section{Masculine domination and Bourdieu's 'practical Mediterraneanism'}

Bourdieu's most explicit and continuous reference to the Mediterranean cultural region appears in the interventions that surround and culminate in Masculine domination. He makes his regionalist intentions clear in a 1990 article, 'La Domination Masculine'. Here, he attributes to a wide swathe of Mediterranean cultures a consistency with respect to attitudes towards honour and shame:

One can be convinced of the cultural unity of Mediterranean societies (of the present or of the past, like Ancient Greece) and of the particular place of Kabyle society by consulting the set of studies dedicated to the problem of honour and shame in different Mediterranean societies, Greece, Italy, Spain, Egypt, Turkey, Kabylia, etc. ${ }^{44}$

The reference to Ancient Greek culture commits Bourdieu to the strongest Mediterraneanist claims. The uncanny character of the Mediterranean as a category, according to Herzfeld, derives from the place of Greece, which is 'cast by the citizens of more powerful states in the conflicting roles of quintessential source of European culture and undisciplined Mediterranean peasantry'. ${ }^{45}$ Clearly, Bourdieu does not attribute these roles to the Kabyle. He does, however, invoke Ancient Greece, going to great lengths to associate the Kabyle, in particular, with this culture. His discussions with Mouloud Mammeri, in which he draws parallels between Kabyle and Homeric poets, demonstrate this. ${ }^{46}$ Bourdieu argues that within Ancient Greek texts a 'Mediterranean unconscious' is evident. He proceeds to claim that Kabylia, for a number of reasons, acts as a 'conservatory' of this unconscious. ${ }^{47}$ The practices there, he proposes, mobilise in a highly visible fashion the practical categories, the particular gender oppositions, that also appear in these Greek texts. Furthermore, Bourdieu draws a link 
between the Kabyle categories and his 'own mental structures as a man born in the neoMediterranean cultural tradition'. He does not, contrary to some claims, posit an evolutionist path from the Kabyle to the French, which would render the former 'archaic forerunners' rather than descendants of a common ancestor ${ }^{48}$ Rather, he presents the Kabyle as a 'particular case of the possible', one variant on the Mediterranean androcentric culture. This culture, which they display in stark form, 'haunts our unconscious'. 49

It haunts our unconscious in the form of a system of cognitive oppositions homologous to that of male/female - like straight/bent, front/back, up/down, outside/inside, hard/softwhich, Bourdieu argues, serve to justify a social order that is gendered in numerous ways. This cognitive and corporeal system does so by both enacting and expecting certain behaviours and, upon finding these expectations fulfilled, attributes them to 'nature', to an inevitable biological difference between the sexes. Throughout the first half of Masculine domination, Bourdieu provides an account of this unconscious system, presenting an abstracted version of the Kabyle gendered worldview in a glaring and blunt form. It is in the second half of the book that Bourdieu describes 'our' societies, noting at the outset that the function of the detour through the Kabyle worldview is to provoke a feeling of unsettled recognition. While others have criticised Bourdieu's text for its apparent exoticism or its lack of attention to changes in gender relations in Kabylia, ${ }^{50} \mathrm{I}$ wish instead to point out the gratuitousness of Bourdieu's detour through Kabylia. That is, we should ask what we gain from the recognition that such a distinction between, for example, the 'hard' and the 'soft' sciences is analogous to the masculine/feminine practical distinction instituted in Kabylia? Recourse to this case is not necessary to establish what was by then known from studies of attitudes among Westerners. That is, what is the function of this unnecessary trip outside of the context of Western Europe? Why must we 'detour through an exotic tradition' to show to those who inhabit Europe something about themselves that sociological work has already shown them? ${ }^{51}$

Its function rests precisely on provoking in the reader a scandalised response, a shock predicated on the expectation that the reader will resist recognising herself in a presumed exotic tradition. Because of this explicit concern with the reader and the effects of the text, Bourdieu's Masculine domination is a convenient selection given our concern with performative statements. He speculates that 'the experience of the unprepared reader' of the text will range from a feeling of banal recognition to 'a form of disconcertation, which may be accompanied by an impression of revelation, or, more precisely, of rediscovery'. 
Masculine domination can thus be considered the most overtly political of his scholarly texts. In the preface to the English and German translations of this work, Bourdieu takes the time to describe the logic underlying it, stating that it examines the mechanisms by which an order of sexual division is historically instituted. Uncharacteristically, from this logic, Bourdieu extracts a general political lesson: 'Combating these historical forces of dehistoricisation must be the most immediate objective of an enterprise of mobilisation aimed at putting history in motion again by neutralising the mechanisms of the neutralisation of history'. He proceeds to call for a 'strictly political mobilisation...oriented towards legal and political reforms'.52

This political reading, which sees Masculine domination as a manifestation of his 'Realpolitik of reason', is supported if it is correct, as Addi proposes, that Bourdieu's claims are empirically flawed. Addi suggests that the kind of masculine domination observed in France, in which women are more likely to be socially subordinated and excluded from certain spaces and activities on account of their gender, is distinct from the kind associated with Kabylia. This is so even if their practical manifestations are similar. The latter form is predicated on the importance of patrilineal descent and the denial of women's contribution to the labour of reproduction, resulting in their effacement within the lineage, manifest in facts like different, and differently valorised, names for paternal and maternal uncles. ${ }^{53}$ If so, Bourdieu's analysis fails as a historical examination of some kind of Mediterranean unconscious, for the manifest practices, however similar they appear, have distinct causal principles. Thus, Bourdieu's claims can be taken as intuitive rhetorical postulates, attempts to universalise his claims, rather than empirical claims about Mediterranean cultural traits. We ought to then question the mirror analogy that Bourdieu himself deploys here: what is the status of the image thrown back if the causal processes underlying it are discrepant? This seems to be a clear instance of misrecognition. Bourdieu's Mediterranean — as exemplified by the Kabyle_functions, then, as a mirror whose image is vague enough that anybody can recognise herself in it. This claim is supported by his attempt to extend the scope of contemporary cultures who owe their 'masculine cosmogony' to this particular mythico-cultural fount: speaking to a Berkeley audience in 1996, Bourdieu claims that 'it lies behind our own European and even EuroAmerican cultural tradition'. Such a claim renders sensible the further proposition that it serves as the source for the anthropological assumptions of even a Jewish Viennese man like Freud. ${ }^{54}$ North Africa, Europe, and the lands colonised by countries from the latter, then, all appear to owe their attitudes to this particular region. Herein lies the second element of 
Bourdieu's practical Mediterraneanism: it ostensibly serves as the hinge for a historical account of the universal.

Bourdieu's method here reveals something about his attitude to the dialectic between the particular and the universal. He asserts widely and paradoxically that immersed study of the particular enables one to extract universals or 'invariants'. That is, the universal lodges itself within the particular, enabling the 'ethnosociologist [to be] a kind of organic intellectual of humanity, ...placing his skill at the service of a universalism rooted in the comprehension of different particularisms'. ${ }^{55}$ Yet this appears to be a presumed universalism, just as a trait like honour is presumed to prevail throughout the Mediterranean, only subject to translation. This resolves the paradox of the universal within the particular-for the particular was not so originally, since Bourdieu begins from the premise that all practices can be substituted within a structure. $^{56}$

\section{Loss and reappropriation}

By turning to the universalist pretence of Bourdieu's sociology, we are closer to understanding how the exotic Kabyle can be depicted as familiar: precisely because practices are substitutable within a system of differences, they cannot but be familiar - their exotic disguise notwithstanding. Bourdieu's personal remarks on the 'labour of reappropriation' express this ambivalence: studying the Kabyle, he confesses, enabled him to reclaim certain traits he had relinquished. He states that 'it was Algeria that enabled me to accept myself. The gaze of the understanding that I applied to Algeria, I could then apply to myself, to the people of my region, to my parents, my father's accent... ${ }^{57}$ By seeing certain traits in the deforming mirror of an apparently exotic culture, he could reappropriate them. These traits are both his and not his, for it is only because they were 'other' - sufficiently distant from him - that they could be shorn of their stigma and reappropriated.

All of this is only possible in a framework of the substitutability of practices. This suggests again that despite their necessarily exotic façade, Bourdieu's Kabyle are rather quite familiar. Therefore, we can follow Hage, who writes that in contrast to somebody like Lucien LévyBruhl, 'Bourdieu...offers no conception of such radical otherness' ${ }^{58}$ To pursue the mirror metaphor that presented itself at the outset, we could say that while the Kabyles offered a reflection in which Bourdieu could recognise himself otherwise, the 'anti-narcissistic' aim 
should be, as Maniglier asserts, 'to return to us an image in which we do not recognise ourselves'. ${ }^{59}$ This would replace Bourdieu's approach with Rimbaud's famous 'I is an other' formula; for the sociologist, on the contrary, 'an other is I'. The exotic is a priori domesticated.

I wish to conclude by making a suggestion for future inquiry concerning Bourdieu's relation to Kabylia, and in particular concerning the conditions of possibility for this 'a priori domestication', for this (mis)recognition of the other as oneself. This takes us back to the colonial conditions in which this depiction is founded, but by revising how we conceive of both colony-metropole relations and Bourdieu's field theory. As Steinmetz suggests, Bourdieu's field theory should be revised by an expansion beyond the borders of the nationstate. ${ }^{60}$ This is especially the case for those spaces defined as empires or colonial networks. It is perhaps particularly apt for French Algeria, for this land was-at least nominally'integral' to the metropole. If we think of the French social space as extending to encompass Algeria, we can more precisely explain Bourdieu's uncanny depiction of the Kabyles: here, the Mediterranean becomes a kind of denied or transmuted version of this imperial social space, and Bourdieu's affinity becomes one of homology. The Béarnais become analogous to the 'dominated fraction of the dominant class', finding in the dominated-the colonial subject, from whom one is not a just sea apart but with whom one is joined in social spacesome affective bond. Perhaps this is too hasty a speculation, for it requires rigorous reconstruction of this social space, and a determination as to whether it is possible to delineate as such. Indeed, Steinmetz claims that there are practices that persist outside of social space, in which one 'lack[s] control of any and all power or resources'. This is, he adds, 'particularly crucial in colonial situations, where pre-existing social relations and institutions are often shattered without anything new taking their place'. This would certainly include the resettled Algerians whom Bourdieu and Sayad studied. But even if indigenous Algerians were not, throughout the colonial period, deprived of all power or resources in such a brutal manner, it is not clear that they would belong to a social space continuous with the metropole.

Finally, we must draw a consequence from the fact that Bourdieu's biographical circumstances, invoked constantly and implicated in his work as epistemological strategies, cannot be ignored in understanding his relation to the other. It is possible that a psychoanalytic framework could supplement the analysis presented here predicated on 
practical Mediterraneanism. Indeed, my concluding postulation, that the Mediterranean could be a denied transmutation of the French-Algerian imperial social space, depends on such a conceptual apparatus. Once again, Steinmetz offers some direction in this regard: it is a variation of 'the widespread phenomenon of the colonizer's cross-identifications with the colonized'. ${ }^{61}$ By taking up such a vocabulary, we can rework the position I took at the outset while invoking Bourdieu's allodoxia, the 'false recognition founded on the misrecognised relation between two histories that brings one to recognise oneself in another history'. This is perhaps a playful allusion on Bourdieu's part to Lacan's 'misrecognition'. As such, the sociologist's account can be sustained with more attention to the psychological mechanisms at play.

By attending to the 'uses' that Bourdieu makes of his representations of the Kabyle in various points of his work, we encounter his 'practical Mediterraneanism', the performative instantiation of this region. For him, this is a way resolving his ambivalent position, transmuting a colonial relation into a cultural one, perhaps substituting the Mediterranean region for social space of the French empire, within which Bourdieu occupied a homologous position to those whom he was originally marshalled to control. It follows that the inextricability of self and other in Bourdieu's system of representations is an objective product of the conditions in which he found himself.

\section{Notes}

${ }^{1}$ Tassadit Yacine, 'Pierre Bourdieu, amusnaw kabyle ou intellectuel organique de l'humanité', in Rencontres avec Pierre Bourdieu, Mauger, Gerard Paris: Editions du Croquant, 2005, p 565-74, p 572.

${ }^{2}$ Dionigi Albera, 'Entre deux rives: Pierre Bourdieu, l'anthropologie et la Méditerranée', in L'Algérie sociologique: hommage à Pierre Bourdieu (1930-2002), Chachoua, Kamel Algiers: CNRPAH, 2012, p 59-72, p 62; Alban Bensa, 'Pierre Bourdieu et l'anthropologie', in La liberté par la connaissance: Pierre Bourdieu (1930-2002), Bouveresse, Jacques and Daniel Roche Paris: Odile Jacob, 2004, p 249-80, p 265.

${ }^{3}$ Pierre Bourdieu, 'Le mort saisit le vif: les relations entre l'histoire réifée et l'histoire incorporée', Actes de la recherche en sciences sociales 32-33, 1980, p 3-14, p 14. 
${ }^{4}$ Michael Herzfeld, Anthropology through the looking-glass: critical ethnography in the margins of Europe, Cambridge, UK: Cambridge University Press, 1987, p 7.

${ }^{5}$ Deborah Reed-Danahay, “Tristes Paysans”: Bourdieu's early ethnography in Béarn and Kabylia', Anthropological Quarterly 77(1), 2004, p 87-106, p 95; 94; see also Raymond Jamous, 'Pierre Bourdieu et les études kabyles', Awal: Cahiers d'Etudes Berbères 27-28 2003, p 111-22.

${ }^{6}$ Pierre Bourdieu, Algerian sketches, Malden, MA: Polity Press, 2013, p 292.

${ }^{7}$ Michael Herzfeld, 'Practical Mediterraneanism: excuses for everything, from epistemology to eating', in Rethinking the Mediterranean, Harris, W.V. Oxford: Oxford University Press, 2005, p 45-63.

${ }^{8}$ Jane E. Goodman, 'The proverbial Bourdieu: habitus and the politics of representation in the ethnography of Kabylia', American Anthropologist 105(4), 2003, p 782-93, p 782. ${ }^{9}$ Enrique Martín-Criado, Les deux Algéries de Pierre Bourdieu, Broissieux: Éditions du Croquant, 2008, p 295; Raewyn Connell, Southern theory: the global dynamics of knowledge in social science, Crows Nest, NSW: Allen \& Unwin, 2007; Jane E. Goodman and Paul A. Silverstein, 'Introduction: Bourdieu in Algeria', in Bourdieu in Algeria: colonial politics, ethnographic practices, theoretical developments, Goodman, Jane E. and Paul A. Silverstein Lincoln: University of Nebraska Press, 2009, p 1-62; Jeremy Lane, Pierre Bourdieu: a critical introduction, London: Pluto Press, 2000; Deborah Reed-Danahay, Locating Bourdieu, Bloomington: Indiana University Press, 2005.

${ }^{10}$ Julian Go, 'Decolonizing Bourdieu: colonial and postcolonial theory in Pierre Bourdieu's early work', Sociological Theory 31(1), 2013, p 49-74; George Steinmetz, 'Bourdieu, historicity, and historical sociology', Cultural Sociology 5(1), 2011, p 45-66; Tassadit Yacine, 'Pierre Bourdieu in Algeria at war: notes on the birth of an engaged ethnosociology', Ethnography 5(4), 2004, p 487-509.

${ }^{11}$ Goodman and Silverstein, 'Introduction', p 4; Martín-Criado, Les Deux Algérie.

${ }^{12}$ Goodman and Silverstein, 'Introduction', p 14; Pierre Bourdieu, Sociologie de l'Algérie, Paris: Presses Universitaires de France, 1958.

${ }^{13}$ Camille Lacoste-Dujardin, 'A propos de Pierre Bourdieu et de l' « Esquisse d'une théorie de la pratique »', Hérodote 2(2), 1976, p 103-16, p 111; Edward W. Said, 'Representing the colonized: anthropology's interlocutors', Critical Inquiry 15(2), 1989, p 205-25, p 223. ${ }^{14}$ Herzfeld, Anthropology through the looking-glass, p 8; p 83. 
${ }^{15}$ Deborah Reed-Danahay, 'The Kabyle and the French: Occidentalism in Bourdieu's Theory of Practice', in Occidentalism: images of the West, Carrier, James Oxford: Oxford University Press, 1995, pp 61-84, p 67; p 64.

${ }^{16}$ Jeremy Lane, “Domestiquer l'exotique... exotiser le domestique': the symbiosis of ethnology and sociology in the work of Pierre Bourdieu', Modern \& Contemporary France 5(4), 1997, pp 445-56, p 453; 455.

${ }^{17}$ Reed-Danahay, “"Tristes Paysans”, p 89; 87; see also Lane, Pierre Bourdieu, p 115, for a discussion of Bourdieu's express awareness of this 'Kabyle myth' and his attempts to escape its implications.

${ }^{18}$ Edward W. Said, Orientalism, New York: Pantheon Books, 1978, p 23; see also David Scott, Refashioning futures: criticism after postcoloniality, Princeton: Princeton University Press, 1999.

${ }^{19}$ Goodman and Silverstein, 'Introduction' p 2.

${ }^{20}$ Here, Bourdieu writes that: 'Perhaps it might be better to write the whole of this essay in the past tense. Indeed, the dislocations which Algerian society has suffered as a result of contact with Western civilization and of the colonial situation'. 'The attitude of the Algerian peasant toward time', in Mediterranean countrymen : essays in the social anthropology of the Mediterranean, Pitt-Rivers, Julian A. Westport: Greenwood press, 1963, p 55, n.1.

${ }^{21}$ Goodman and Silverstein, 'Introduction', p 20; p 19; Kamel Chachoua, 'Pierre Bourdieu et l'Algerie: le savant et la politique', in L'Algérie sociologique: hommage à Pierre Bourdieu (1930-2002), Chachoua, Kamel Algiers: CNRPAH, 2012, pp 9-26.

${ }^{22}$ Quentin Skinner, Regarding method, Visions of politics, Cambridge, UK: Cambridge University Press, 1988, pp 115-16.

${ }^{23}$ Michel de Certeau, The practice of everyday life, Volume 1, Berkeley: University of California Press, 1984, p 51.

${ }^{24}$ Herzfeld, Anthropology through the looking-glass, p 7.

${ }^{25}$ Patricia Lorcin and Todd Shepard, 'Introduction', in French Mediterraneans: transnational and imperial histories, Lorcin, Patricia and Todd Shepard Lincoln: University of Nebraska Press, 2016, pp 1-18, p 1; Iain Chambers, Mediterranean crossings: the politics of an interrupted modernity, Durham, NC: Duke University Press, 2008.

${ }^{26}$ Herzfeld, 'Practical Mediterraneanism', p 47.

${ }^{27}$ Herzfeld, 'Performing Comparisons: Ethnography, Globetrotting, and the Spaces of Social Knowledge', Journal of Anthropological Research 57(3), 2001, pp 259-76, p 266. 
${ }^{28}$ Herzfeld, 'Practical Mediterraneanism', p 57.

${ }^{29}$ Pierre Bourdieu, Language and symbolic power, Cambridge: Polity Press, 1991, p 220.

${ }^{30}$ Bourdieu, Esquisses algériennes, Liber, Paris: Seuil, 2008, p 275.

${ }^{31}$ Bourdieu, 'Le Nord et le Midi: contribution à une analyse de l'effet Montesquieu', Actes de la recherche en sciences sociales 35, 1980, pp 21-25, p 22.

${ }^{32}$ Hafid Adnani and Tassadit Yacine, 'L'autre Bourdieu: celui qui ne disait pas ce qu'il avait envie de cacher', Awal: Cahiers d'Etudes Berbères, 27-28, 2003, pp 229-47, p 239.

${ }^{33}$ Herzfeld, 'Practical Mediterraneanism', p 57; João de Pina-Cabral, 'The Mediterranean as a Category of Regional Comparison: A Critical View', Current Anthropology 30(3), 1989, pp 399-406, p 400.

${ }^{34}$ See Albera, 'Entre deux rives'; Isac Chiva, 'Pierre Bourdieu: “une ethnographie particulière"', Awal: Cahiers d'Etudes Berbères 27-28 2003, pp 39-46; Reed-Danahay, Locating Bourdieu.

35 Julian A. Pitt-Rivers, ed. Mediterranean countrymen: essays in the social anthropology of the Mediterranean (Paris: Mouton, 1963), p 10; p 11.

${ }^{36}$ Bourdieu, Algerian sketches, p 216.

${ }^{37}$ Adnani and Yacine, 'L'autre Bourdieu', p 40; Loïc J. D. Wacquant, 'Following Pierre Bourdieu into the field', Ethnography 5(4), 2004, p 387-414, pp 389.

${ }^{38}$ Goodman and Silverstein, 'Introduction', p 27.

${ }^{39}$ Adnani and Yacine, 'L'autre Bourdieu', $\mathrm{p} 240$.

${ }^{40}$ Pierre Bourdieu and Loïc J. D. Wacquant, An invitation to reflexive sociology, Chicago: University of Chicago Press, 1992, p 163.

${ }^{41}$ Reed-Danahay, “"Tristes Paysans”, p 89.

${ }^{42}$ Bourdieu and Wacquant, An Invitation, p 209.

${ }^{43}$ George Steinmetz, 'Defensive Anthropology', Postcolonial Studies, 17(4), 2014, pp 436$450, \mathrm{p} 442$.

${ }^{44}$ Pierre Bourdieu, 'La Domination Masculine', Actes de la recherche en sciences sociales 84, 1990, pp 2-31, p 5.

${ }^{45}$ Michael Herzfeld, 'The Horns of the Mediterraneanist Dilemma', American Ethnologist 11(3), 1984, pp 439-54, p 442.

${ }^{46}$ Bourdieu, Algerian sketches p 225. For Bourdieu's reference to Mammeri as a 'prudent man', which he translates into 'Aristotle's phronesis, a very Kabylian concept' see Bourdieu, 'La réappropriation de la culture reniée: à propos de Mouloud Mammeri', in Amour, 
phantasmes et sociétés en Afrique du Nord et au Sahara, Yacine, Tassadit Paris:

L'Harmattan-Awal, 1992, pp 17-22, p 22.

${ }^{47}$ Bourdieu, 'Nouvelles réflexions sur la domination masculine', Cahiers du Genre, 33, 2002, pp 225-33, p 226.

${ }^{48}$ Bourdieu, 'Masculine domination revisited', Berkeley Journal of sociology, 41, 1997, pp 189-203, p 192; Tony Bennett, 'The historical universal: the role of cultural value in the historical sociology of Pierre Bourdieu', The British Journal of Sociology 56(1), 2005, pp $141-64, \mathrm{p} 158$.

${ }^{49}$ Bourdieu, 'Masculine domination revisited', p 192; 'Social Space and Symbolic Space: Introduction to a Japanese Reading of Distinction', Poetics Today 12(4), 1991, pp 627-38, p 628.

${ }^{50}$ See Camille Lacoste-Dujardin, Opération Oiseau bleu: des Kabyles, des ethnologues et la guerre, Paris: La Découverte, 1997.

${ }^{51}$ See, e.g., Helen Weinreich-Haste, 'What sex is science?', in Sex-role stereotyping: collected papers, Hartnett, Oonagh, Gill Boden, and Mary Fuller London: Tavistock, 1979, pp 168-81; Pierre Bourdieu, Masculine domination, Cambridge, UK: Polity Press, 2001, p 3. ${ }^{52}$ Bourdieu, Masculine domination p 54; p 55; $\mathrm{p}$ viii.

${ }^{53}$ Lahouri Addi, Sociologie et anthropologie chez Pierre Bourdieu: Le paradigme anthropologique kabyle et ses conséquences théoriques, Paris: Éditions la Découverte, 2002, p 100.

${ }^{54}$ Bourdieu, 'Masculine domination revisited', p 192; Masculine domination, $\mathrm{p} 6$.

${ }^{55}$ Bourdieu, Algerian sketches, p 294.

${ }^{56}$ Bourdieu, 'Social Space and Symbolic Space', p 628.

${ }^{57}$ Bourdieu, Algerian sketches, p 312; 'La réappropriation de la culture reniée: à propos de Mouloud Mammeri', pp 20-21.

${ }^{58}$ Ghassan Hage, 'Eavesdropping on Bourdieu's philosophers', Thesis Eleven, 114(1), 2013, pp 76-93, p 91.

${ }^{59}$ Patrice Maniglier, 'La parenté des autres: à propos de Maurice Godelier', Critique, 701, 2005, pp 758-74, p 774. See Eduardo Viveiros de Castro, Cannibal Metaphysics: For a PostStructural Anthropology, Minneapolis: Univocal Publishing, 2014.

${ }^{60}$ George Steinmetz, 'On Bourdieu, Sur l'État: Field Theory and the State, Colonies, and Empires', Sociologica 8(3), 2014, pp 1-13, p 8; 'Social fields, subfields and social spaces at 
the scale of empires: explaining the colonial state and colonial sociology', The Sociological Review Monographs 64(2), 2016, pp 98-123, p 108.

${ }^{61}$ Steinmetz, The Devil's Handwriting: Precoloniality and the German Colonial State in Qingdao, Samoa, and Southwest Africa, Chicago: University of Chicago Press, 2007, p 60. 


\section{University Library}

\section{- M M N E R VA A gateway to Melbourne's research publications}

Minerva Access is the Institutional Repository of The University of Melbourne

Author/s:

MEAD, G

Title:

The Case of Kabylia: Explaining Elective Affinities in Bourdieu's Mediterranean

Date:

2016

Citation:

MEAD, G. (2016). The Case of Kabylia: Explaining Elective Affinities in Bourdieu's Mediterranean. Postcolonial Studies, 19 (3), pp.325-341. https:// doi.org/10.1080/13688790.2016.1278817.

Persistent Link:

http://hdl.handle.net/11343/123465 